\title{
Isotopic Characterization of Precipitation, Inflow, and Outflow of Lake Toba as a First Assessment of Lake Water Balance Study
}

\author{
P. Sidauruk , B. Pratikno and E.R. Pujiindiyati \\ Center for Isotop and Radiation Application, National Nuclear Energy Agency \\ Jl. Lebak Bulus Raya No. 49, Jakarta 12070, Indonesia
}

\section{ARTICLE INFO}

\section{Article history:}

Received 31 October 2016

Received in revised form 24 August 2017

Accepted 31 August 2017

\section{Keywords:}

Stable isotopes

Oxygen-18

Deuterium

Lake Toba

Rain water

Local meteoric water line

\begin{abstract}
A B S T R A C T
Isotopic characterization of all identified hydrological units in Lake Toba such as precipitation, inflows, outflows, and lake water, as a first assessment of lake water balance study, has been conducted. The isotopic characterization was done through the interpretation of the relationship of $\delta D$ and $\delta^{18} O$ values of collected samples from various water sources and their variations as a function of time and space. Rain water samples were collected from four rain collectors that were installed in the study area in a monthly sampling for a period of 12 months in 2014. Several samples from various water sources i.e., inflow streams, outflows, springs, and lake water, were also collected 2-3 times during this sampling period. From monthly sampling of rain water, local meteoric water line $(L M W L)$ and the equation of elevations versus $\delta D$ values have been constructed. Due to the slightly higher temperature in the study area compared with the average temperature on the other parts of the world, the slope of the constructed $L M W L$ is slightly less than the slope of global meteoric water line. Based on the equation of elevations versus $\delta D$ values, the elevations of four springs around study area have been identified. From the linear relationship of $\delta D$ and $\delta^{18} O$ values of collected samples from inflow streams, it was found that most of the samples have experienced evaporation process before entering the lake. Due to mixing with other surface water and longer transit time, the $\delta D$ and $\delta^{18} O$ values of those samples from streams in the Sumatran side are more enriched than those samples from streams in the Samosir side. It was also found that lake water has experienced significant evaporation as indicated by the $\delta D$ and $\delta^{18} O$ values that were more enriched than any other samples. The $\delta D$ and $\delta^{18} O$ of Asahan River samples, the only output of Lake Toba, were found to be very close to the $\delta D$ and $\delta^{18} O$ of the lake. This is because almost all water that flowed in Asahan River originated from the lake.
\end{abstract}

(C) 2018 Atom Indonesia. All rights reserved

\section{INTRODUCTION}

Lake Toba is located about $150 \mathrm{~km}$ south of Medan, the capital city of North Sumatra. The location of the study is depicted in Fig. 1. Lake Toba is the largest lake in Indonesia and the largest volcanic lake in the world. The lake is about $100 \mathrm{~km}$ long and about $30 \mathrm{~km}$ wide. It stretches from $2.88{ }^{\circ} \mathrm{N}, 98.52{ }^{\circ} \mathrm{E}$ to $2.35{ }^{\circ} \mathrm{N}, 99.1{ }^{\circ} \mathrm{E}$. The maximum depth is estimated to be $505 \mathrm{~m}[1,2]$. The normal surface water elevation is about $905 \mathrm{~m}$

*Corresponding author.

E-mail address: pastons@batan.go.id

DOI: https://doi.org/10.17146/aij.2018.547 above sea level (asl) and the volume is estimated to be $2.4 \times 10^{11} \mathrm{~m}^{3}$ [3]. The lake is surrounded by seven regencies of North Sumatra Province, namely Tapanuli Utara, Humbang Hasundutan, Toba, Samosir, Simalungun, Karo, and Dairi. Lake Toba is the main tourist destination in North Sumatra. It is also the main water sources of the surrounding area for domestic, agriculture, fishery, and power generation. The catchment and the surface areas of the lake are about $3,565 \mathrm{~km}^{2}$ and $1,120 \mathrm{~km}^{2}$, respectively. Hence, the ratio of total catchment area to the lake surface area is only about 3:1. Lake Toba is very susceptible to human activities in terms of quantity and quality. This is because of the very 
small ratio of total catchment area to the lake surface area and the leakage of untreated sewage from domestic waste and agriculture. It has been reported that the water level of Lake Toba has declined 3-5 m below its normal level during the year 1984-1987 [1]. It has also been observed that water hyacinths have degraded the quality and the beauty of the lake for the past two decades [4]. It is then very important to practice good lake management to conserve the quantity as well as the quality of the lake. Natural and human factors are the main driving force for lake deterioration. However, in most cases, human activities are the dominant driving force for the lake deterioration as confirmed by previous studies [5-7]. In lake management, any environmental decision should be made through holistic consideration of all ecological, economic, and social aspects [8].

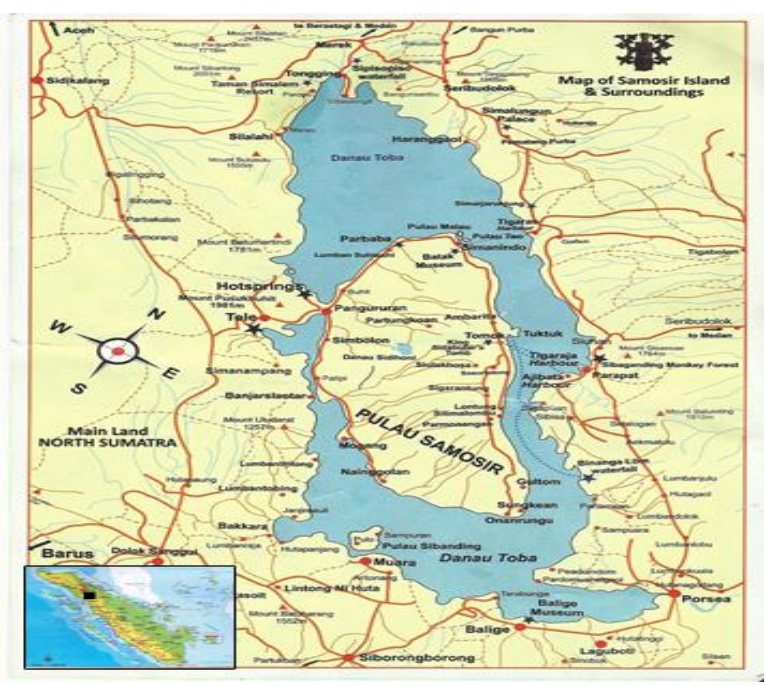

Fig. 1: The location of the study [10].

The government of Indonesia through the collaboration of the State Ministers of Environment and for Research and Technology, and Ministers of Forestry, Home Affairs, Public Works, Agriculture, Energy and Mineral Resources, Maritime Affairs and Fisheries, and Culture and Tourism have agreed in implementation of an Integrated Lake Basin Management (ILBM) programs that was officially announced during the first National Conference of Indonesian Lakes in Bali on August 13 ${ }^{\text {th }}, 2009$ [9]. Under this agreement, 15 lakes including Lake Toba have been chosen to be priority lakes for the implementation of ILBM. Several qualitative and quantitative aspects are considered in lake management to sustain the use of the lake to enhance human lives and the ecosystem. The study of the relationship among all hydrological units such as inflow, outflow, and pooled water is very important. In this study, stable isotopic contents of collected samples from various sources were used to characterize identified inputs such as rain water, inflows, outflows, and lake water. The isotopic characterization of all hydrological units is meant as a first assessment of the water balance of the lake.

Stable isotopes oxygen-18 $\left({ }^{18} \mathrm{O}\right)$ and deuterium $\left({ }^{2} H\right.$ or $\left.D\right)$ are among constituents of water molecules. The variations of ${ }^{18} \mathrm{O}$ and $D$ concentrations in water bodies are caused by several meteoric processes, i.e., condensation, sublimation, and evaporation. In precipitation, for instance, the variations of ${ }^{18} \mathrm{O}$ and $D$ concentrations in a particular region are controlled by transportation of moisture from the evaporated ocean to that particular region. Hence, ${ }^{18} \mathrm{O}$ and $\mathrm{D}$ concentration variations are very good as tracers and are becoming the primary natural tracers that can be used to describe the water cycle and the interaction of several water bodies such as rainwater, lake inflows, outflows, and ponded water [11].

\section{THEORY}

${ }^{18} \mathrm{O}$ and $\mathrm{D}$ are part of the constituents of water molecules. Three different molecules of water that are normally used by hydrologists are $\mathrm{H}_{2}{ }^{16} \mathrm{O}(18)$, $\mathrm{HD}^{16} \mathrm{O}(19)$, and $\mathrm{H}_{2}{ }^{18} \mathrm{O}(20)$ in which the number in the bracket represents molecular mass. In nature, the abundance of $\mathrm{HD}^{16} \mathrm{O}$ and $\mathrm{H}_{2}{ }^{18} \mathrm{O}$ are extremely small compared with the abundance of $\mathrm{H}_{2}{ }^{16} \mathrm{O}$. For this reason, in practice, the abundance of $\mathrm{H}_{2}{ }^{18} \mathrm{O}$ or $H D^{16} \mathrm{O}$ is not measured absolutely but instead is measured in isotopic abundance ratios $\left(\mathrm{H}_{2}{ }^{18} \mathrm{O} / \mathrm{H}_{2}{ }^{16} \mathrm{O}\right.$ or $\mathrm{HD}^{16} \mathrm{O} / \mathrm{H}_{2}{ }^{16} \mathrm{O}$, respectively). These isotopic abundance ratios are compared with the corresponding isotopic ratios of an international standard and expressed in in permil (\%o) and given in (1a) and (1b) [12]:

$$
\delta^{18} O=\left(\frac{\left[\mathrm{H}^{2}{ }^{18} \mathrm{O} / \mathrm{H}_{2}{ }^{16} \mathrm{O}\right]_{S}}{\left[\mathrm{H}_{2}{ }^{18} \mathrm{O} / \mathrm{H}_{2}{ }^{16} \mathrm{O}\right]_{S t}}-1\right) \times 1000 \%
$$

and

$$
\delta D=\left(\frac{\left[H D^{16} \mathrm{O} / \mathrm{H}_{2}{ }^{16} \mathrm{O}\right]_{s}}{\left[H D^{16} \mathrm{O} / \mathrm{H}_{2}{ }^{16} \mathrm{O}\right]_{s t}}-1\right) \times 1000 \%
$$

In the equations, subscripts $s$ and $s t$ stand for sample and standard, respectively. The widely accepted international standard is the Standard Mean Ocean Water (SMOW). If a given water body or water vapor undergoes physical processes, e.g., condensation, evaporation, or sublimation (phase change) then the original values of $\delta^{18} \mathrm{O}$ and 
$\delta D$ will change. These values will either increase (enrich) or decrease (deplete). These phenomena are caused by isotopic fractionation due to molecular mass difference among the three molecules.

The isotopic fractionation will be affected by several factors such as average temperature, altitude, latitude, and distance from shoreline. For example, precipitations in higher average temperatures tend to be more enriched in $\delta^{18} O$ and $\delta D$ values compared with those in lower temperatures. On the other hand, precipitations in higher altitudes will be more depleted in $\delta^{18} O$ and $\delta D$ values [13,14].

The change of $\delta D$ is linearly correlated with the change of $\delta^{18} \mathrm{O}$ in meteoric water. The linear relationship between $\delta D$ and $\delta^{18} O$ in precipitation from several rain stations over the world was first established by Craig in 1961 and is given in (2) [15]:

$$
\delta D=8 \delta^{18} O+10
$$

Equation (2) is commonly called Global Meteoric Water Line $(G M W L)$. The slope of local meteoric water line $(L M W L)$, however, may be different from eight. In tropical countries such as Indonesia, the slope of $L M W L$ is commonly less than eight, due to fractionation effect caused by the higher temperature in tropical countries. In general, the $L M W L$ equation can be written as:

$$
\delta D=a \delta^{18} O+c
$$

Equation (3) implies that the intercept of the $L M W L$ is not always 10 as given in (2). Another important parameter in precipitation study is deuterium excess (d). Deuterium excess can be viewed as the deviation index of any precipitation at particular time or region with global meteoric water and defined in the following formula [16]:

$$
d=\delta D-8 \delta^{18} O
$$

While the slope $a$ of $L M W L$ is normally affected by the average surface temperature at the precipitation site, d-excess $(d)$ correlates with the physical condition of the ocean (humidity and temperature of the air as well as the temperature of the ocean surface) from which the water vapor was generated before being transported to precipitation site [17].

It is also important to mention that surface water or any evaporated body has the slope of linear relationship of $\delta D$ and $\delta^{18} O$ of less than eight in general. This phenomenon is again caused by isotopic fractionation effect.

\section{METHODOLOGY}

In the current study, the $\delta^{18} O$ and $\delta D$ values and their variations as a function of time and space were employed to elaborate the characteristics of all hydrological components and their interactions. The samples were collected from lake water, inflows, outflows, and rain water. The samples from lake water, inflows, and outflows were collected from several sampling points 2-3 times during the year 2014. There were many streams flowing into the lake; however, few of them were perennial streams. On the other hand, the only outflow from the lake is the Asahan River. The locations of the sampling points are given in Fig. 2.

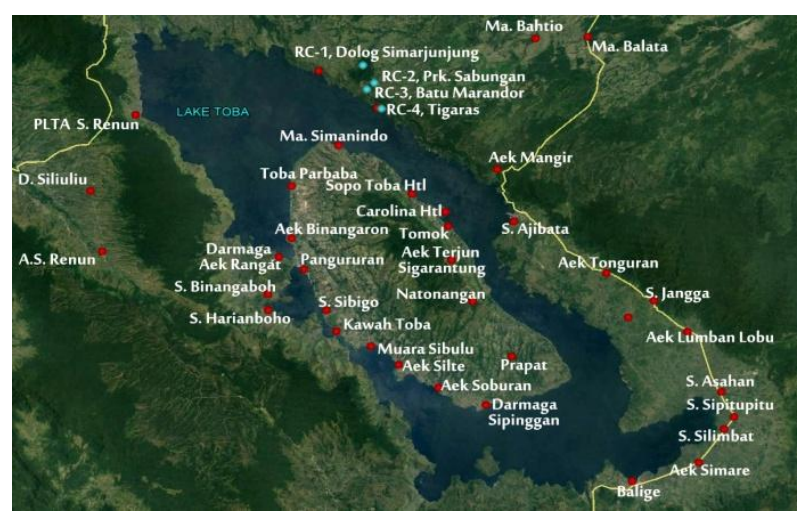

Fig. 2. Location of sampling points.

Four rain collectors were installed at four different locations. The elevation of the four rain collectors ranged from 923-1497 $\mathrm{m}$ above sea level with approximately 150-200 m relative difference in elevation from a lower position to a higher position of rain collectors. The locations, coordinates, and elevations of the rain collectors are given in Table 1. One sample from each rain collector was collected every month for stable isotopes analysis. To cover both dry and rainy seasons, the duration of sample collection was set to be 12 months. To avoid evaporation of water inside rain collector between sampling periods, about $200 \mathrm{~cm}^{3}$ paraffin oil was poured into rain collector and let to float above water surface inside the rain collector.

Table 1. Location, coordinate, and the elevation of the rain collectors

\begin{tabular}{llccc}
\hline Code & Location & \multicolumn{2}{c}{ Coordinate $(\mathrm{m})$} & Elevation \\
\cline { 3 - 4 } & & East & North & $(\mathrm{m})$ \\
\hline RC-1 & Simarjarungjung & 313650 & 474734 & 1497 \\
RC-2 & Siambataon & 311341 & 475758 & 1350 \\
RC-3 & Marandor & 310899 & 475280 & 1200 \\
RC-4 & Tiga Ras & 309350 & 476014 & 923 \\
\hline
\end{tabular}

In this study, stable isotopes were the main tools that were used to characterize rain water, inflows, outflow, and lake water. However, for some selected sampling points, two different samples were collected that is one was for stable isotope analysis ( $\delta^{18} O$ and $\delta D$ values) and the other 
one was for chemical analysis. For stable isotopes analysis, approximately $20 \mathrm{~cm}^{3}$ of water was collected into air tide bottle and free of bubble. This is to minimize isotopic fractionation due to evaporation during samples transportation or storage. For chemical analysis, on the other hand, $500 \mathrm{~cm}^{3}$ of water was collected into double-cap plastic container.

$\delta^{18} \mathrm{O}$ and $\delta D$ values were measured using a laser-based instrument, the Liquid Water Isotope Analyzer (LWIA), with a precision of $0.2 \%$ for $\delta D$ and $0.03 \%$ for $\delta^{18} \mathrm{O}$.

\section{RESULTS AND DISCUSSION}

\section{Precipitation}

The measured monthly intensity of rain for each rain collector is given in Table 2. The empty data (-) indicates either a dry month or an intensity that was too small that it was let to accumulate for the next sample collection. Using the date from the four rain collectors, it was found that annual rain intensity around Lake Toba in 2014 was about $3200 \mathrm{~mm}$.

Table 2: Monthly rain intensity of the four installed rain collectors

\begin{tabular}{lrrrr}
\hline \multirow{2}{*}{$\begin{array}{l}\text { Month } \\
(2014)\end{array}$} & \multicolumn{4}{c}{ Rain Intensity (mm) } \\
\cline { 2 - 5 } January & \multicolumn{1}{c}{ RC-2 } & RC-3 & \multicolumn{1}{c}{ RC-4 } \\
February & 97.43 & 97.43 & 90.94 & - \\
March & 159.14 & 318.28 & 250.08 & - \\
April & 498.53 & 662.54 & 0.00 & 733.99 \\
May & 324.77 & 487.16 & 264.69 & 617.07 \\
June & 487.16 & 48.72 & 237.08 & 87.69 \\
July & - & - & - & - \\
August & 337.76 & 344.26 & 467.67 & 448.19 \\
September & 357.25 & 552.11 & 328.02 & 211.10 \\
October & 415.71 & 462.80 & 444.94 & 259.82 \\
November & 529.38 & 545.62 & 438.44 & 227.34 \\
December & 487.16 & - & 513.14 & - \\
\hline
\end{tabular}

The $\delta^{18} O$ and $\delta D$ values of all samples are given in Table 3.

Table 3. $\delta^{l} O$ and $\delta D$ values of monthly rain water samples

\begin{tabular}{ccccccccc}
\cline { 2 - 9 } Mo. & $\delta \Delta$ & $\delta^{18} O$ & $\delta \Delta$ & $\delta^{18} O$ & $\delta \Delta$ & $\delta^{18} O$ & $\delta \Delta$ & $\delta^{18} O$ \\
& $(\%$ ) & $(\% \circ)$ & $(\% o)$ & $(\% o)$ & $(\% o)$ & $(\% o)$ & $(\% o)$ & $(\% o)$ \\
\hline Jan & - & - & - & - & - & - & - & - \\
Feb & -32.0 & -5.7 & -28.7 & -6.8 & -29.6 & -6.1 & -30.7 & -6.5 \\
Mar & -39.0 & -7.0 & -38.0 & -10.1 & -37.4 & -6.7 & - & - \\
Apr & -70.6 & -10.0 & -67.6 & -9.3 & - & - & -56.3 & -9.3 \\
May & -59.6 & -8.4 & -69.6 & -8.3 & -65.4 & -7.5 & -61.4 & -9.4 \\
Jun & -63.8 & -9.4 & -59.9 & -4.0 & -66.7 & -9.7 & -38.2 & -5.2 \\
Jul & - & - & - & - & - & - & - & - \\
Aug & -14.5 & -2.6 & -20.9 & -2.8 & -15.3 & -3.1 & -13.2 & -2.7 \\
Sep & -35.0 & -5.1 & -15.0 & -5.3 & -18.2 & -3.7 & -45.2 & -5.2 \\
Oct & -36.9 & -4.8 & -37.1 & -5.6 & -36.2 & -4.9 & -38.2 & -5.2 \\
Nov & -38.2 & -5.4 & -39.5 & -6.8 & -33.2 & -4.7 & -26.8 & -3.7 \\
Dec & -37.3 & -5.2 & - & - & -32.6 & -5.7 & - & - \\
\hline
\end{tabular}

\section{Local meteoric water line ( $L M W L)$}

The Local Meteoric Water Line $(L M W L)$ is very important in hydrological cycle study. $L M W L$ is a reference for many studies such as evaporation, condensation, and interaction of surface water and groundwater. The $L M W L$ is the linear line developed from the graph of the $\delta^{18} O$ versus the $\delta D$ of precipitation data. The data from rain collector \#4 (RC-4) were excluded in developing $L M W L$ due to the fact that some disturbances occurred related to data collection from RC-4, such as unavailability of paraffin oil inside the rain collector during data collection and over-capacity because of the late collection of the sample. The exclusion of data from RC-4 was to avoid misleading results. In addition, two pairs of data have been treated as outliers and hence excluded from the construction of $L M W L$. The outliers were determined through statistical analysis on the calculated deuterium excess $(d)$ values. Deuterium excess values were calculated using (4). The range of deuterium excess values was found to range from -27.9 to 42.8 . The two outliers correspond with deuterium excess $d=-27.9$ (RC-2, June) and $d=42.8$ (RC-2, March). The regression equation of $L M W L$ after exclusion of the outliers from rain collectors $\mathrm{RC}-1, \mathrm{RC}-2$, and $\mathrm{RC}-3$ was given in (5) and Fig. 3.

$$
\delta D=7.74 \delta^{18} O+7.82
$$

The coefficient of determination $r^{2}=0.81$ indicates that the data well fit the linear regression line. The slope $(a)$ of the $L M W L$ that is very close to $8(a=7.74)$ indicates that the effect of isotope fractionation was not very significant. This phenomena is normal because the average temperature in the region is only about $20{ }^{\circ} \mathrm{C}$ [18]. The intercept $d=7.82$ which is less than 10 indicates that the water vapor was transported from warmer ocean [13]. This phenomenon is also expected in tropical country like Indonesia where all surrounding oceans are warm all year round. Further, this $L M W L$ will be used as a reference for hydrological cycle studies in the vicinity of the study area.

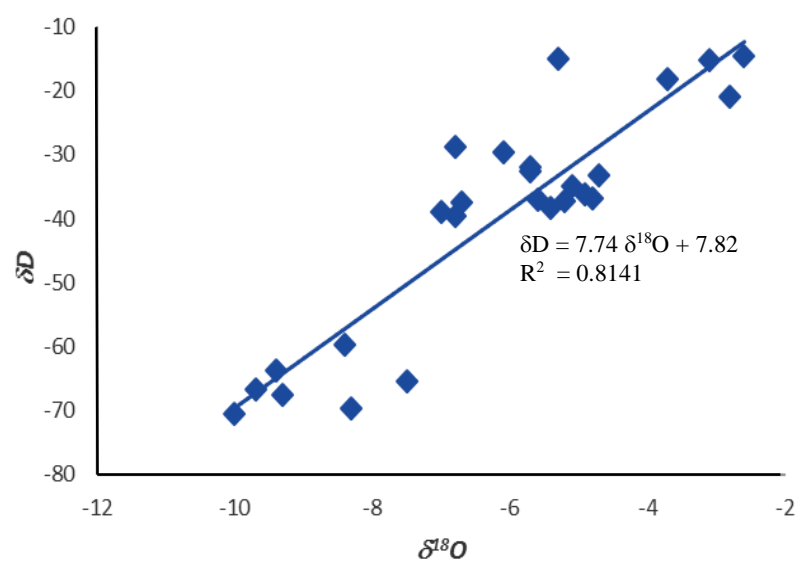

Fig. 3. Graph of $\delta D$ versus $\delta^{8} O(L M W L)$. 
Figure 4 presents the linear relationship between $\delta D$ and elevation. Figure 4 was constructed by first calculating the weighted average of $\delta D$ values at each rain station using the following formula:

$$
\bar{\delta} D=\frac{\sum_{i=1}^{n} c_{i} \delta D_{i}}{\sum_{i=1}^{n} c_{i}}
$$

In (6), $\bar{\delta} D, \delta D_{i}$ represent the weighted average and the monthly $\left(i^{\text {th }}\right.$ month) isotopic ratios of $D$, respectively; and $c_{i}$ represents rain intensity at the $i^{\text {th }}$ month.

The equations of the linear lines are given in (7).

$$
\bar{\delta} D=-0.022 E-9.05
$$

or

$$
E=-45.45 \bar{\delta} D-411.36
$$

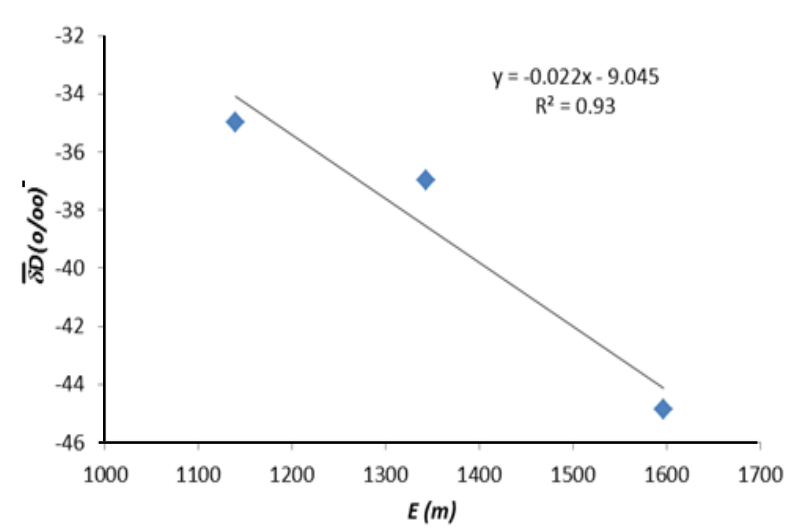

Fig. 4. Graph of $\delta D$ versus Elevation $(E)$ of rain water samples.

Because groundwater and springs are isolated from the atmosphere during their migration from the recharge point to discharge point (sampling point), the $\delta^{8} O$ and $\delta D$ values of groundwater and springs can be assumed to be similar to $\delta^{18} O$ and $\delta D$ values of rain water at recharge point. Hence, (7a) and (7b) are very important for estimating the elevation of recharge area of any groundwater or springs around the study area. In the present study, most of the samples were collected from surface water, and only four samples were from springs, while none was from groundwater. The names of the four springs, together with their average $\delta D$ values and calculated elevation of recharge area using (7b), are given in Table 4.

Table 4. Isotopic ratios of samples from springs

\begin{tabular}{llcc}
\hline No & Springs & $\bar{\delta} D(\%)$ & Elev. $(\mathrm{m})$ \\
\hline 1 & Jangga & -55.8 & 2121.96 \\
2 & Panahatan & -51.6 & 1931.28 \\
3 & Sampuran Sihotang & -52.5 & 1972.14 \\
4 & Naibaho & -49.1 & 1817.78 \\
\hline
\end{tabular}

Since all of the springs were in the Sumatra Island side, the calculated elevations given in Table 4 can be justified and make sense since all of them are within the catchment area of Lake Toba that is in the Sumatra Island side.

\section{Surface water samples}

Surface water samples were mostly collected from the streams or rivers that flowed into Lake Toba. Table 5 presents the name of all surface water samples together with their $\delta^{18} O$ and $\delta D$ values, while the corresponding graph of $\delta^{18} O$ versus $\delta D$ is given in Fig. 5 . The equation of the linear regression line for $\delta^{18} O$ versus $\delta D$ as shown in Fig. 5 is given in (8) below.

$$
\delta D=4.89 \delta^{18} O-21.47
$$

It can be seen from (8) that the slope of the regression line is much less than the slope of $L M W L$ that was given in (5). This indicates that all of the surface water samples have undergone evaporation process before entering Lake Toba. The same phenomenon has also been observed by one of the authors during the study of "Hydraulic interconnections study of SeropanNgreneng-Bribin underground rivers in Gunung Kidul karst area using tracer technique" [19]. In the study, it was found that the slope of the linear relationship between $\delta^{18} O$ and $\delta D$ values in the underground rivers was 4.77 which is very close to the present study result of 4.89 .

Further observation reveals that, in general, those samples collected from mainland Sumatra were more enriched than those collected from the Samosir Island. This can be explained as follows: the streams in the Sumatra Island side were in general longer than those streams in the Samosir Island, causing those samples collected from the Sumatran side to have experienced a longer evaporation process than those from the Samosir Island side. It was also observed during the sample collection that those streams in the Sumatran side had significantly mixed with excess water from paddy farms. Additionally, it has been discussed in the previous sections that those streams in the Samosir Island side only flow intermittently during rainy season, making their $\delta^{18} O$ and $\delta D$ values not very different than the corresponding $\delta^{18} O$ and $\delta D$ values of rain samples. 
Table 5. Isotopic ratios of surface water samples

\begin{tabular}{clcc}
\hline No. & River Name & & $\delta D(\% o)$ \\
& & $\delta^{18} O(\%$ oo & \\
\hline 1 & Silubung & -10.06 & -69.5 \\
2 & Rianiate & -9.74 & -71.2 \\
3 & Sibulu & -9.99 & -70.1 \\
4 & Jangga & -10.37 & -69.4 \\
5 & Silinta & -10.40 & -70.2 \\
6 & Hatoguan & -9.22 & -62.8 \\
7 & Sigumbang & -9.49 & -70.0 \\
8 & Soburan-2 & -9.78 & -70.7 \\
9 & Situa-tua & -9.53 & -69.4 \\
10 & Soburan & -8.64 & -66.2 \\
11 & Sialimut & -9.00 & -67.9 \\
12 & Hairi & -8.71 & -69.0 \\
13 & Binanga Aron & -8.66 & -68.5 \\
14 & Bolon & -9.79 & -70.7 \\
15 & Sigarantung fall & -10.25 & -68.1 \\
16 & Nainggolan & -10.03 & -73.2 \\
17 & Renun & -7.29 & -58.6 \\
18 & Siliu-liu Dam & -7.88 & -58.2 \\
19 & Lumban Lobu-2 & -9.46 & -68.1 \\
20 & Simare & -6.15 & -51.2 \\
21 & Mandosi & -9.47 & -64.0 \\
22 & Bonan Dolok & -6.63 & -52.5 \\
23 & Galian & -7.89 & -53.5 \\
\hline & & &
\end{tabular}

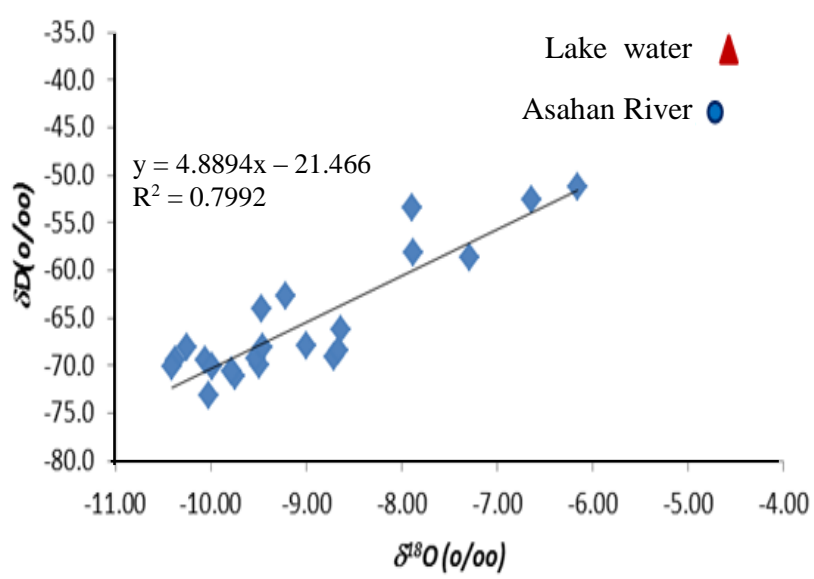

Fig. 5. Graph of $\delta D$ versus $\delta^{l 8} O$ of samples collected from surface water.

\section{Output and lake water samples}

The output of Lake Toba is only through the Asahan River. Water samples from Asahan River were collected at the upstream of the river before any other streams merge with the river. The average $\delta^{18} O$ and $\delta D$ values of collected samples were $-4.78 \%$, and $-44.30 \%$, respectively. On the other hand, lake water samples were collected from several sampling points namely Tiga Ras, Parapat, Sihotang, and Balige at the Sumatran side and Simanindo, Pangururan, Sipinggan, and Sopo Toba at the Samosir side. At the current study, all of the lake water samples were collected from the shore lines. The average $\delta^{18} O$ and $\delta D$ values of collected lake water samples were $-4.57 \%$, and $-37.20 \%$, respectively. Both $\delta^{18} O$ and $\delta D$ values of collected from Asahan River and Lake Toba are depicted in Fig. 5 together with those $\delta^{18} O$ and $\delta D$ values that were collected from inflow streams.

It can be observed from Fig. 5 that $\delta^{18} O$ and $\delta D$ values of both Asahan River and lake samples are very similar. This phenomenon is as expected because the samples from Asahan River were collected at the upstream of the river before any other streams merge with the river. Most of the water flows in this part of the river were originated from the lake. The only other water that may have mixed with lake water was that water came from domestic waste water. It is also observed from Fig. 5 that $\delta^{18} O$ and $\delta D$ values of lake water are much more enriched than those samples from inflow streams or rivers. This indicates that the lake water had further experienced significant evaporation process as expected due to long residence time of the lake.

\section{CONCLUSION}

From $\delta^{18} O$ and $\delta D$ values of monthly rain waters, the local meteoric water line $(L M W L)$ and the equation of linear relationship between elevation and $\delta D$ values have been constructed for the vicinity of the study area. Although there were four rain collectors installed in the study area, the constructed $L M W L$ and elevation versus $\delta D$ values were only based on three installed rain collectors. The data from one rain collector (RC-4) was eliminated because of inadequate sampling procedures. The slope of $L M W L$ that is less than the slope of global meteoric water line $(G M W L)$ is typical in tropical countries such as Indonesia. In this study, the constructed $L M W L$ had been used as a reference for meteoric process studies of various water samples. Based on the constructed equation of relationship of between elevations versus $\delta D$ values, the elevations of the recharge areas of four springs in the study area were identified.

From the graph of $\delta^{18} O$ versus $\delta D$ of all samples collected from inflow streams, it was found that the slope of the regression line between $\delta^{18} O$ and $\delta D$ was much less than the slope of $L M W L$. This indicates that all of the surface water samples had undergone evaporation process before entering Lake Toba. The samples collected from mainland Sumatra were more enrich than those collected from the Samosir Island. This is partly because the streams in the Sumatran side are in general longer than those streams in the Samosir Island, causing those samples collected from the Sumatran side to have experienced longer evaporation process than 
those from the Samosir side, and partly because those streams in the Sumatran side had significantly mixed with excess water from paddy farms.

The $\delta^{18} O$ and $\delta D$ values of both Asahan River and lake samples were very similar. This was because most of the water flowing in this part of the river originated from the lake. The $\delta^{18} O$ and $\delta D$ of lake water were much more enriched than those from inflow streams or rivers. This is because that the lake water had experienced significant evaporation due to the long residence time of the lake.

\section{ACKNOWLEDGMENT}

The authors acknowledge that this study was funded by the Government of Indonesia through BATAN Research Fund (DIPA) of year 2014. They also thank the laboratory assistants for providing them with the results of stable isotope and chemical analysis of the samples.

\section{REFERENCES}

1. M.C. Acreman, J.R. Meigh and K.J. Sene, Adv. Water Resour. 16 (1993) 207.

2. C.A. Chesner, Quat. Int. 258 (2012) 5. DOI:10.1016/j.quaint.2011.09.025

3. B. Gopal, D. Ghosh and N. Delhi, Ref. Modul. Earth Syst. Environ. Sci. Encycl. Inl. Waters (2009) 501.

4. M. Irham, T. Nasution, S. Muhamad et al., Int. J. Environ. Sci. Dev. 7 (2016) 630.

5. Z. Yang, F. Wu and X. Gao, Phys. Chem. Earth 96 (2016) 26. DOI:10.1016/j.pce.2016.06.006

6. B.J. Huser, M. Futter, J.T. Lee et al., Water Res. 97 (2016) 142.

DOI:10.1016/j.watres.2015.07.036
7. M. Lurling, E.B. Mackay, K. Reitzel et al., Water Res. 97 (2016) 1.

DOI:10.1016/j.watres.2016.03.035

8. R. Goodspeed, C. Riseng, K. Wehrly et al., Mar. Policy 69 (2016) 134.

DOI:10.1016/j.marpol.2016.04.017

9. T.R. Soeprobowati, Procedia Environ. Sci. 23 (2015) 368. DOI:10.1016/j.proenv.2015.01.053

10. Anonymous, https://dynamicjourneys.blogspot. co.id/ 2013/08/my-Trip-to-Lake-Toba.html (2013).

11. E.R. Pujiindiyati and P. Sidauruk, Atom Indonesia 41 (2015) 31.

DOI:10.17146/aij.2015.553

12. P. Zhao, X. Tang, P. Zhao et al., J. Hydrol. $\mathbf{5 0 3}$ (2013) 1. DOI:10.1016/j.jhydrol.2013.08.033

13. Z. Pang, Y. Kong, K. Froehlich et al., Tellus 63B (2011) 352. DOI:10.1111/j.16000889.2011/00532.x

14. Y. Kong, Z. Pang, J. Hydrol. 542 (2016) 222. DOI:10.1016/j.jhydrol.2016.09.007

15. J. Sánchez-españa, M. Diez, F. Pérez et al., J. Hydrol. 511 (2014) 494.

DOI:10.1016/j.jhydrol.2014.02.003

16. F. Aemisegger, S. Pfahl, H. Sodemann et al., Atmos. Chem. Phys. 14 (2014) 4029. DOI:10.5194/acp-14-4029-2014

17. S. Pfahl and H. Sodemann, Clim. Past $\mathbf{1 0}$ (2014) 771. DOI:10.5194/cp-10-771-2014

18. H. Sihotang, M.Y.J. Purwanto, Widiatmaka et al., J. Nat. Resour. Environ. Manag.2 (2012) 65. (in Indonesian)

19. P. Sidauruk, R. Prasetio and S. Satrio, Int. J. Water 12 (2018) 39. 